\title{
Household Income Dynamics and Investment in Children: Evidence from India
}

\author{
Sowmya Dhanaraj \\ Smit Gade \\ Christy Mariya Paul
}

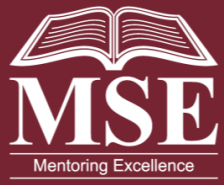

MADRAS SCHOOL OF ECONOMICS

Gandhi Mandapam Road

Chennai 600025

India

July 2018 


\section{Household Income Dynamics and Investment in Children: Evidence from India}

\section{Sowmya Dhanaraj}

Assistant Professor, Madras School of Economics

Corresponding Author

sowmya@mse.ac.in

Smit Gade

Good Business Lab

\section{Christy Mariya Paul}

Madras School of Economics 
WORKING PAPER 177/2018 MADRAS SCHOOL OF ECONOMICS

Gandhi Mandapam Road

Chennai 600025

India

July 2018

Phone: 2230 0304/2230 0307/2235 2157

Fax : $22354847 / 22352155$

Email : info@mse.ac.in

Price : Rs. 35

Website: www.mse.ac.in 


\title{
Household Income Dynamics and Investment in Children: Evidence from India
}

\author{
Sowmya Dhanaraj, Smit Gade and Christy Mariya Paul
}

\begin{abstract}
Income shocks on households in developing countries are known to have an impact on the investment in the education of children. In this paper, we explore the effects of various income and expenditure shocks on educational investment and cognitive outcomes of children. In order to understand the mechanisms through which shocks affect children's human capital we employ a range of dependent variables that capture input, output and outcome measures of education. We use three rounds of household-level panel data from Young lives survey conducted in two southern states of India, Andhra Pradesh and Telangana. Dynamic Panel data model using system General Method of Moments (GMM) estimator is used for investigating the impact of various income and expenditure shocks on children's education and cognitive abilities. We find that idiosyncratic shocks like paternal health shocks and livestock loss translate into lower inputs of children's education which in turn reduce their cognitive ability captured through vocabulary and mathematics tests. The results also suggest that these shocks mainly affect children's development through decreased time spent in school.
\end{abstract}

Key words: income shocks, child time use, test scores, dynamic panel estimation

JEL Codes: I20, I24, I30 


\section{Acknowledgement}

The paper was presented in 13th Annual Conference on Economic Growth and Development held in ISI Delhi, and 4th International Conference on South Asian Development held in SAU, Delhi and MSE-CUTN faculty seminar held in CUTN, Thiruvarur. The comments received from the conference/seminar participants helped improve the contents of the paper. Special thanks to Dr. Vidya Mahambare and Dr. Anup Bhandari for their comments on an earlier draft of the paper.

Sowmya Dhanaraj

Smit Gade

Christy Mariya Paul 


\section{INTRODUCTION}

Human development is a fundamental part of economic development. Human development is the result of an accumulated investment in growing children including nutrition, education, simulation and care in a supportive environment (Lundberg and Wuermli, 2012). Investment in the education of children is vital for the human capital formation and productivity in later years. Family plays a critical role in the development of child human capital through their decision to enrol children in school, keep children in school, determining their time allocation between work and study, providing the physical resources, providing emotional care etc. Families' decisions regarding investment in the human capital of their children have long-run consequences for their welfare (Ferreira and Schady, 2009). Due to the role played by the family, the decisions that households make in response to fluctuations in household income affects the children. In this paper, we investigate the impact of household income or expenditure shocks on the education of children.

Households in developing countries are frequently exposed to a broad array of shocks. These shocks cause disruption in households along with large income fluctuations (Morduch, 1995). Shocks can be classified into two types - idiosyncratic shocks and covariate shocks. Idiosyncratic shocks are those that affect individual households like illness, injury or death of family members, job loss, farm or business loss, theft or destruction of property. Covariate shocks are aggregate shocks that affect groups of households, communities, regions or even entire countries like natural disasters, changes in food prices, economic crisis. The shocks can be both positive and negative. In this paper, we focus on negative shocks.

Developing countries are characterised by lower income levels, more shocks and lower opportunities for the diversification of such shocks, because of thin insurance markets and the comparatively more acute presence of borrowing constraints (Fitzsimons, 2007). These 
characteristics of developing countries create the need for households to build alternative ways of coping with risk. If households can smooth income (by diversifying into production activities which entail low levels of risk) or consumption (through borrowing, saving and insurance mechanisms), then income fluctuations are not likely to translate into welfare loses for shock-exposed households. In less developed countries, where incomes are low and erratic, the impact of market incompleteness on human capital accumulation is potentially large (Jacoby and Skoufias, 1997). It is often argued that households in the absence of complete or perfect markets, when faced with adverse shocks resort to various coping strategies like drawing on savings, increasing family labor supply (inserting non-working family members into the labor market or increasing the number of hours worked), accessing formal (government supported social assistance) or informal (remittances, charities, nongovernmental organizations, borrowing) safety nets, and reducing household expenditures (durable goods, food, clothing, etc.) and human as well as financial investments (Dasgupta and Ajwad, 2011). In many cases, children can also be used as risk coping instruments.

Existing literature has estimated the impact of various shocks on educational outcomes in developing countries such as: Weather shocks (Jensen, 2000; Thai and Falaris, 2014; Shah and Steinberg, 2017; Abiona, 2007; Zamand and Hyder, 2016), macroeconomic shocks (Hou et. al., 2016; Cogneau and Jedwab, 2012; Ferreira and Schady, 2009; Singh, 2011), farm yield or job loss (Duryea et. al., 2007; Guarcello et. al., 2010; Janvry et. al., 2006; Dasgupta and Ajwad, 2011; Beegle et. al., 2003; Glick et. al., 2016), health shocks (Woode, 2017; Dinku et. al., 2018; Sun and Yao, 2010; Woldehanna and Hagos, 2012; Evans and Miguel, 2007), and fertility shocks (Kpein et. al., 2012; Glick et. al., 2007).

These studies consider various indicators of education to test the impact on education which can be classified into input, output and outcome variables. For instance, (i) input variables such as expenditure 
on education (Dasgupta and Ajwad, 2011) and decision to enroll in school (Ferreira and Schady, 2009; Guarcello et. al., 2010), (ii) output variables such as school enrolment (Cogneau and Jedwab, 2012; Janvry et. al., 2006; Jensen, 2000), school dropout (Duryea et. al., 2007; Dung, 2013; Glick et. al., 2016), child labour (Beegle et. al., 2003; Singh, 2011), schooling, study time etc. and (iii) outcome variables such as Cloze Test, PPVT (Peabody Picture Vocabulary Test) and mathematics test Scores (Crookston et. al., 2014; Fink and Rockers, 2014; Shah and Steinberg, 2017; Singh and Sarkar, 2015; Zamand and Hyder, 2016) are used to capture investment in education.

In this paper, we expand the existing literature in a number of ways. There have been studies that analyse the impact of various shocks on the investment in education, but such studies are rare in the Indian context, mostly due to unavailability of longitudinal data on shocks and investments in children. Those studies that have analysed the impact of shocks on children's human capital focus on specific indicators only. Moreover, these studies concentrate on one or two shocks. Such an approach does not throw light on the mechanism through which shocks affect investments in human capital. In this paper, we examine the impact of a wide variety of shocks, both covariate and idiosyncratic shocks on child human capital. This is because some households may be exposed to multiple shocks simultaneously, for instance, weather shocks may lead to crop loss as well as ill-health. Such multi-shocks studies help to better understand which shocks predominate, and which have intergenerational effects in terms of translating to poorer outcomes for children's human capital. In the Indian context, the studies that analysed investment in child human capital focused on economic and household characteristics. Those limited number of studies that have assessed the impact of shocks have mainly focused on health shocks and climatic shocks only. This paper examines the impact of various shocks on input indicators of education (time spent on school, time spent on studies outside school, time spent on work), output indicators (enrolment, grade advancement) and finally outcome indicators that measure cognitive 
achievement of children (PPVT test and mathematics test). The following section details about the data used in the study.

\section{DATA}

This paper uses longitudinal dataset of Young Lives project that follows the lives of approximately 12,000 children in four low and middle-income countries (Ethiopia, India, Peru, and Vietnam). In India, the survey is conducted in the state of Andhra Pradesh (now Andhra Pradesh and Telangana), and four rounds have been completed so far (2002, 2006 and 2009 and 2013). The sample consists of two age-groups of children: the younger cohort of 2011 children of age between 6 and 18 months during round one in 2002 and an older cohort of 1008 children then aged between 7.5 and 8.5 years. The survey has rich information on the health status, school enrolment, and attainment, cognitive and non-cognitive abilities. In this paper, we use the data from the younger cohort.

The young lives children are selected from 20 sentinel sites. The survey uses semi-purposive sampling method. The sampling method is as follows: Andhra Pradesh has three distinct agro-climatic regions Telangana, Rayalaseema and Coastal Andhra. One poor and one nonpoor district is chosen from each region based on a set of development indicators. In addition to the six districts, Hyderabad district, capital of Andhra Pradesh is also included. From these districts, twenty mandals (sub-districts) are selected as sentinel sites based on a set of socioeconomic indicators. These mandals or sentinel sites are further divided into four contiguous geographical areas, and one village is randomly selected from each area. From the sentinel sites, 100 households with a child born in 2001-02 and 50 households with a child born in 1994-95 were randomly selected (Young lives survey design and sampling in India, 2014).

Young lives study has low attrition rate when compared to other longitudinal studies. The attrition rate is 2.6 percent for the Younger 
Cohort and 4.3 percent for the Older Cohort since the beginning of the study. The main reasons for attrition are migration (both internal and abroad), marriage (non-participation due to the disapproval of in-laws), and the feeling that no tangible benefits have been brought by the study (Galab et. al., 2011).

This paper focuses on investment in education. This data set has several features that make it particularly appropriate for the proposed analysis. Young lives survey provides rich information on child education. It includes information on the enrollment status of children, highest grade completed, time use, and scores of various tests administered to check the cognitive ability of the child. The time use of children provides information on how much time the children spend on sleeping, leisure, studying both in and out of school, and working (both paid and unpaid). For cognitive ability, The Peabody Picture Vocabulary Test (PPVT) was administered. PPVT uses stimulus words and accompanying pictures to test receptive vocabulary. In India, the test was adopted in the native tongue of children (predominantly Telugu). Maths test items consisted of questions related to addition, subtraction, multiplication, division, problem-solving, measurement, data interpretation, and basic geometry. Table 1 presents summary statistics on child education for the rounds two, three and four of the survey for younger cohort. For the younger cohort, there is almost universal enrolment into schools with around 99 percent of children enrolled in primary education in Round three. There is a slight drop in enrolment rate in Round four as they move to upper primary education. The average time spent in paid activities is negligible across all the rounds. Time spent in studies (both at home and school) increase from Round two to Round four. Time spent on unpaid work increased from Round two to four whereas time spent on leisure activities decreases in subsequent rounds. PPVT score increase from Round two to three, but then it decreases later in Round 4 while there is no significant change in Math test score. 
Table 1: Indicators of Investments in Children's Education

\begin{tabular}{|l|c|c|c|}
\hline \multirow{2}{*}{ Variable } & \multicolumn{3}{c|}{ Younger Cohort } \\
\cline { 2 - 4 } & $\mathbf{R 2}$ & $\mathbf{R 3}$ & $\mathbf{R 4}$ \\
\hline Enrolment & 89.4 percent & 99.0 percent & 97.2 percent \\
\hline Grade completed & 0.2 & 1.7 & 5.4 \\
\hline Grade advanced & - & 1.6 & 3.9 \\
\hline $\begin{array}{l}\text { Time spent on unpaid work } \\
\text { (in Hours) }\end{array}$ & 0.2 & 0.6 & 1.1 \\
\hline $\begin{array}{l}\text { Time spent on paid work (in } \\
\text { Hours) }\end{array}$ & 0.0 & 0.0 & 0.1 \\
\hline $\begin{array}{l}\text { Time spent on leisure } \\
\text { activities (in Hours) }\end{array}$ & 14.0 & 13.9 & 13.0 \\
\hline $\begin{array}{l}\text { Time spent on studies (in } \\
\text { Hours) }\end{array}$ & 6.1 & 9.5 & 9.9 \\
\hline PPVT score & 90.3 & 130.8 & 43.1 \\
\hline Maths test score & - & 12.0 & 12.8 \\
\hline
\end{tabular}

Source: Author's own compilation based on Young Lives survey.

The Young Lives survey includes a separate section for collecting information about the shocks and adverse events that affect households. In each survey round, households are asked if they have suffered from any shocks or adverse events that affected their income since the previous survey. A large number of shocks and negative events are specified in each round. The reported shocks can be broadly classified into different groups namely natural disaster, crop shock, livestock shock, paternal health shock, maternal health shock, job shock, divorce shock, fertility shock, education expenditure shock, crime shock, price shock, housing damage shock, regulatory and economic shocks, and other shocks.

Table 2 gives the percentage of households affected by different income shocks. Crop loss or damage and natural disaster are the major shocks that caused a reduction in the economic well being of households. Health shock is the next major shock affecting the households. 
Table 2 : Shocks Faced By Households (Younger Cohort)

\begin{tabular}{|l|c|c|c|c|}
\hline \multicolumn{1}{|c|}{ Type of shocks } & $\begin{array}{c}\text { Between } \\
\text { child birth } \\
\text { and Round } \\
\text { 1 (per cent) }\end{array}$ & $\begin{array}{c}\text { Between } \\
\text { Round 1 } \\
\text { and Round } \\
\text { 2 (per cent) }\end{array}$ & $\begin{array}{c}\text { Between } \\
\text { Round 2 } \\
\text { and Round } \\
\text { 3 (per cent) }\end{array}$ & $\begin{array}{c}\text { Between } \\
\text { Round 3 } \\
\text { and Round } \\
\text { 4 (per cent) }\end{array}$ \\
\hline Crop loss / damage & 28.2 & 18.2 & 21.5 & 24.6 \\
\hline Livestock loss/ disease & 5.8 & 6.3 & 7.7 & 7.7 \\
\hline Health shock & 18.5 & 28.7 & 18.4 & 32.9 \\
\hline Natural Disaster & 22.3 & 30.6 & 9.7 & 14.6 \\
\hline Fertility shock & 7.4 & 18.4 & 4.5 & 1.1 \\
\hline Divorce/ separation & 1.4 & 3.5 & 1.2 & 0.7 \\
\hline Education expenditure & 3.2 & 4.1 & 7.5 & 3.5 \\
\hline Crime & 5.9 & 5.7 & 4.2 & 1.9 \\
\hline Price fluctuations & - & 11.1 & 79.4 & 51.7 \\
\hline Job loss & 5.1 & 1.5 & 1.4 & 1.8 \\
\hline Housing damages & - & 1.6 & 1.2 & 0.2 \\
\hline Regulatory/economic shocks & - & 6.4 & 3.0 & 1.3 \\
\hline Other Shocks & 10.5 & 2.6 & 8.9 & 3.5 \\
\hline Observations & 2011 & 1950 & 1931 & 1915 \\
\hline Sourct Auts & & & \\
\hline
\end{tabular}

Source: Authors' own compilation based on Young Lives survey.

Health shocks are seen to be consistently affecting a significant number of households across the four rounds of the survey. Price fluctuations also affect a number of households in the Round two, three and four. Divorce shock has the smallest incidence among the income shocks under consideration. In round one and two, crop shock, health shocks and natural disaster were the most commonly experienced shocks. But in Round three and four, price shocks is the major shock that negatively affected the households.

\section{METHODOLOGY}

This study uses the dynamic panel data model to find the impact of various shocks on investment in the education of children. The difference GMM (Generalised Method of Moments) estimator proposed by ArellanoBond (1991) and system GMM estimator proposed by Arellano-Bover (1995) and Blundell-Bond (1998) are the dynamic panel estimators. These estimators are devised for situations where there are small time 
periods and large number of individuals, a functional relationship that is linear, a single dynamic dependent variable which depends on its own past realizations, independent variables that are not strictly exogenous i.e. correlated with past and possibly current realizations of the error; fixed individual effects; and heteroscedasticity and autocorrelation within individuals, but not across them (Roodman, 2009).

Arellano-Bond estimators are called difference GMM estimators because they start estimation by transforming all independent variables, usually by differencing, and use the Generalized Method of Moments (Hansen 1982). Sometimes, the forward orthogonal deviations transform, proposed by Arellano and Bover (1995), is performed instead of differencing. The system GMM estimator expands the difference GMM estimator by making an additional assumption, i.e., the first differences of instrumenting variables are not correlated with the fixed effects. This can lead to the introduction of more instruments, and can significantly improve efficiency. The system GMM builds a system of two equations, the original equation as well as the transformed one.

Consider the following equations

$$
\begin{gathered}
y_{i t}=X_{i t} \beta_{1}+W_{i t} \beta_{2}+v_{i t} \\
v_{i t}=u_{i}+\varepsilon_{i t}
\end{gathered}
$$

where $X_{i t}$ includes strictly exogenous covariates, $W_{i t}$ are predetermined covariates (which may include lags of $y$ ) and endogenous regressors, all of which may be correlated with $u_{i}$, the unobserved individual effect. $\beta_{1}$ and $\beta_{2}$ are vectors of parameters that has to be estimated. $\varepsilon_{i t}$ are the observation-specific errors (Roodman,2009). First-differencing the equation removes the $u_{i}$ and its associated omitted-variable bias. But, First-differencing differencing predetermined variables that are not strictly exogenous make them endogenous. Therefore, Arellano and Bond (1991) developed a GMM estimator that instruments the differenced variables that are not strictly exogenous (variables that are not correlated with either current or past errors) with all their available lags in levels. The difference GMM estimator faces a problem if the variables are close to a random walk. In those situations, lagged levels are poor instruments 
for first differences. The system GMM estimator solves this problem by using the levels equation to obtain a system of two equations, a differenced equation and the other one in levels. Additional instruments can be obtained by adding the level equation. This leads to an increase in the efficiency. Variables in levels are instrumented with suitable lags of their own first differences. The assumption made is that these differences are uncorrelated with the unobserved individual effects (Mileva, 2007).

We run separate regressions for input indicators of education (time spent in school, time spent in study and time spent doing paid or unpaid work) and outcome indicators that assess the cognitive ability of the children like PPVT scores and math scores. Time spent at school includes travel to school time as well. Time spent on work includes hours spent by the children on paid as well as unpaid work. The shocks that are considered in the paper include drought, flood, crop shock, livestock shock, paternal health shock, maternal health shock, job shock, divorce shock, fertility shock, education expenditure shock and housing damage shock. Crime shock, price shock, regulatory and economic shocks and other shocks are excluded from the model since they are not consistently captured in all the four rounds of the survey (Refer table B1 in Appendix).

Other explanatory variables like age, gender and birth order of the child are included in the model. Household level characteristics like gender of the household head, education (years of schooling) of the household head and mother, wealth index, household size, rural residence, whether the household belongs to disadvantaged group like Scheduled caste (SC), Scheduled tribe (ST), other backward castes (OBC) and Muslims are also included. To account for the fact that some of these variables might itself change in response to shocks, we include lagged values of the time varying factors. For instance, a household might adjust the number of members, break into more households, move to urban residence seeking for jobs, etc. in response to shocks. Hence, we use lagged values of these variables as explanatory factors. We also include 
dummy variables for rounds of the survey. Further, in the regressions we consider shocks as endogenous variables since there might be unobserved characteristics that make certain households more prone to some of the shocks. These unobserved factors might also influence children's educational outcomes through mechanisms other than shocks.

\section{RESULTS}

\section{Effect of Shocks on Input Indicators of Children's Education}

We present our findings of dynamic panel analysis for input indicators of education (time spent in school, time spent in study and time spent doing paid or unpaid work). Results show positive effect of drought on school time while floods increase time spent by children on domestic work. Shah and Steinberg (2017) who found similar results had explain that parents invest more in the education of children in times of drought, because the returns to child labour are lower in comparison with the seasons with high rainfall during which children are more likely to work. Results obtained from the regression finds that paternal health shocks have negative effects on the time spent by children at school whereas maternal health shock reduces only the time spent studying at home. Since father of the household is in most cases the breadwinner, the loss of income caused by the paternal health shock negatively affects the investments in children. Children will not be able to attend school regularly or spend time on studies outside school because they may be required to work to generate additional income to compensate the loss of income caused by the paternal health shock. However, maternal health shocks only reduce the time spent in studying because the children may be required to help in domestic chores or the time spent in hometeaching by mothers who are ill might reduce.

Loss of livestock reduces the study time spent by children at home and school and increases the time spent on paid and unpaid work. We note that more than 40 percent of households in the southern states of Andhra Pradesh and Telangana own livestock and this is one of the 
main sources of income diversification for the rural households. Thus, loss of livestock may cause direct income loss for the household and in order to meet the income fluctuations due to the loss of livestock, children may have to reduce their study time and do some work either at home or outside. The results show that the increase in the education expenditure increases the time spent at school because higher education expenditure might have caused parents to induce their children to spend more time on studies and attend school regularly.

We also find that the girls spend more time on work and less time in schools. This in turn points to the gender bias in educational investments in children which the existing literature has pointed out. Among the other household characteristics, households having a female head have children with higher study time at home and at school in comparison with the households with male heads. 
Table 3: Effect of Shocks on Input Indicators of Education

\begin{tabular}{|c|c|c|c|c|c|c|}
\hline \multirow[b]{3}{*}{ VARIABLES } & \multirow{2}{*}{\multicolumn{2}{|c|}{$\begin{array}{l}\text { (1) }(2) \\
\text { At school }\end{array}$}} & \multirow{2}{*}{\multicolumn{2}{|c|}{$\begin{array}{c}(3) \quad(4) \\
\text { Study at home }\end{array}$}} & \multirow{2}{*}{\multicolumn{2}{|c|}{$\begin{array}{l}(5) \quad(6 \\
\text { Work time }\end{array}$}} \\
\hline & & & & & & \\
\hline & coeff & se & coeff & se & coeff & se \\
\hline gged dependent & -0.020 & 0.017 & 0.050 & 0.033 & $0.075^{* *}$ & 0.038 \\
\hline rop shock & $0.135 *$ & 0.080 & -0.053 & 0.066 & 0.030 & 0.071 \\
\hline rous & 213* & 0.124 & -0.148 & 0.103 & 0.007 & 0.111 \\
\hline ood & -0.022 & 0.155 & -0.167 & 0.129 & $0.529 * * *$ & 0.138 \\
\hline loss & $-0.212 *$ & 0.116 & $-0.176 *$ & 0.096 & $0.273 * * *$ & 0.103 \\
\hline athe & $-0.306 * * *$ & 0.098 & 0.022 & 0.081 & 0.089 & 0.087 \\
\hline oth & $249 * *$ & 0.105 & $-0.203 * *$ & 0.087 & -0.021 & 0.094 \\
\hline & .164 & 0.211 & 0.120 & 0.175 & -0.250 & 0.188 \\
\hline & 350 & 0.419 & -0.395 & 0.349 & 0.612 & 0.374 \\
\hline eet & 0.025 & 0.193 & -0.202 & 0.160 & 0.095 & 0.172 \\
\hline & $0.572^{* * *}$ & 0.124 & -0.161 & 0.103 & -0.033 & 0.110 \\
\hline ous & -0.059 & 0.324 & -0.228 & 0.269 & 0.003 & 0.289 \\
\hline 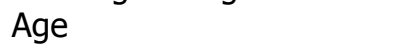 & .002 & 0.006 & $-0.012^{* *}$ & 0.005 & $0.012 * *$ & 0.005 \\
\hline & $-0.122 * * *$ & 0.044 & $0.081 * *$ & 0.037 & $0.328 * * *$ & 0.040 \\
\hline & 0.045 & 0.045 & & 0.038 & $0.075^{*}$ & 0.040 \\
\hline & -0.052 & 0.133 & $0.340 * * *$ & 0.111 & $-0.347 * *$ & 0.119 \\
\hline & $24 * * *$ & 0.007 & & 0.005 & $-0.023 * * *$ & 0.006 \\
\hline & $025 * * *$ & 0.007 & $0.017 * * *$ & 0.006 & $-0.011^{*}$ & 0.006 \\
\hline & & 0.012 & & 0.010 & -0.003 & 0.010 \\
\hline L.w & $530 * * *$ & 0.195 & $0.390 * *$ & 0.162 & -0.238 & 0.173 \\
\hline & & 0.082 & & 0.068 & & 0.073 \\
\hline SC & $-0.184 * *$ & 0.090 & $-0.167 * *$ & 0.075 & 0.011 & 0.080 \\
\hline CT & & 0.069 & & 0.057 & $0.159 * *$ & 0.061 \\
\hline Mus & $-0.273 * *$ & 0.114 & 0.010 & 0.095 & $0.235^{* *}$ & 0.102 \\
\hline & -0.001 & 0.070 & $0.232 * *$ & 0.058 & 0.030 & 0.063 \\
\hline & -0.324 & 0.297 & $-0.525 * *$ & 0.240 & 0.045 & 0.257 \\
\hline & & 0.000 & & 0.000 & & 0.000 \\
\hline & $7.660 * * *$ & 0 & $2.893 * * *$ & 0.728 & -0.754 & 0.775 \\
\hline & 3,4 & & & & 3,415 & \\
\hline & 18 & & 10 & & 051 & \\
\hline
\end{tabular}

Note: L. stands for lagged values of the time-varying variables. ${ }^{* *} p<0.01, * * p<0.05, * p<0.1$

Source: Author's own compilation based on Young Lives survey.

Time spent by children on studies increases and the time spent by them on work decreases with the increase in the years of schooling of the mother and the wealth of the household. Belonging to low 
socioeconomic status groups like Scheduled Tribe, Scheduled Castes and Backward Castes has a negative effect on the study time. ST and Muslim children are more likely to spend more time on work than other children.

\section{Effect of Shocks on Output Indicators of Children's Education}

In the younger cohort, livestock shock, paternal health shock and flooding have negative effect on enrolment. Loss of livestock and paternal health shock may impose resource constraints on the households and in turn it can cause households to reduce the educational investment in children in order to reduce the constraints. Flooding may increase the availability of work due to excessive rainfall and hence children may be pulled out of school to earn extra income. However, we do not find any effect of these shocks on grade completed by the students. We find that children with household and mother highly educated and those belonging to wealthier households are more likely to be enrolled in schools. In the next section, we investigate whether these shocks have permanent effects in terms of coginitive achievement of children. 
Table 4: Effect of Shocks on Output Indicators of Children's Education

\begin{tabular}{|c|c|c|c|c|}
\hline & \multirow{2}{*}{\multicolumn{2}{|c|}{$\begin{array}{cc}\mathbf{( 1 )} & \mathbf{( 2 )} \\
\text { School enrolment }\end{array}$}} & \multirow{2}{*}{\multicolumn{2}{|c|}{$\begin{array}{cc}\mathbf{( 3 )} & \mathbf{( 4 )} \\
\text { Grade completed }\end{array}$}} \\
\hline & & & & \\
\hline & Coefficient & se & Coefficient & se \\
\hline Lagged dependent variable & 0.004 & $(0.013)$ & $0.811^{* * *}$ & $(0.028)$ \\
\hline Drought & 0.017 & $(0.012)$ & -0.041 & $(0.091)$ \\
\hline Flood & $-0.026 *$ & $(0.015)$ & 0.102 & $(0.113)$ \\
\hline Crop shock & 0.008 & $(0.008)$ & -0.072 & $(0.057)$ \\
\hline Livestock loss & $-0.019 *$ & $(0.011)$ & -0.044 & $(0.085)$ \\
\hline Father ill/died & $-0.023 * *$ & $(0.010)$ & -0.057 & $(0.071)$ \\
\hline Mother ill/died & 0.012 & $(0.010)$ & -0.023 & $(0.076)$ \\
\hline Job shock & 0.013 & $(0.021)$ & 0.143 & $(0.156)$ \\
\hline Divorce & -0.002 & $(0.041)$ & -0.249 & $(0.303)$ \\
\hline Fertility shocks & -0.014 & $(0.019)$ & -0.159 & $(0.137)$ \\
\hline Education expenditure & 0.008 & $(0.012)$ & $-0.293 * * *$ & $(0.091)$ \\
\hline Housing damages & -0.045 & $(0.032)$ & $0.396 *$ & $(0.238)$ \\
\hline Child's age & -0.001 & $(0.001)$ & $0.035^{* * *}$ & $(0.005)$ \\
\hline Female & -0.006 & $(0.004)$ & $0.221 * * *$ & $(0.033)$ \\
\hline Eldest child & -0.004 & $(0.005)$ & -0.005 & $(0.034)$ \\
\hline L.female head & 0.008 & $(0.013)$ & -0.042 & (0.099) \\
\hline L. head education & $0.001 *$ & $(0.001)$ & -0.000 & $(0.004)$ \\
\hline Mother education & $0.001 * *$ & $(0.001)$ & $0.019 * * *$ & $(0.005)$ \\
\hline L. household size & -0.000 & $(0.001)$ & 0.008 & $(0.008)$ \\
\hline L. wealth index & $0.042 * *$ & $(0.019)$ & $0.322 * *$ & $(0.141)$ \\
\hline SC & 0.002 & $(0.008)$ & 0.034 & $(0.060)$ \\
\hline ST & 0.002 & $(0.009)$ & $-0.231 * * *$ & $(0.065)$ \\
\hline $\mathrm{OBC}$ & -0.005 & $(0.007)$ & 0.001 & $(0.050)$ \\
\hline Muslims & 0.001 & $(0.011)$ & $-0.287 * * *$ & $(0.083)$ \\
\hline L.rural residence & 0.007 & $(0.007)$ & $0.105^{* *}$ & $(0.053)$ \\
\hline Round 3 & -0.004 & $(0.028)$ & $-2.387 * * *$ & $(0.450)$ \\
\hline Round 4 & 0.000 & $(0.000)$ & $-1.517 * *$ & $(0.650)$ \\
\hline Constant & $1.019 * * *$ & $(0.086)$ & 0.000 & $(0.000)$ \\
\hline Observations & 3,379 & & 3,304 & \\
\hline Number of children & 1,836 & & 1,818 & \\
\hline
\end{tabular}

Note: L. stands for lagged values of the time-varying variables. $* * * p<0.01, * * p<0.05, * p<0.1$

Source: Author's own compilation based on Young Lives survey. 


\section{Effect of Shocks on Outcome Indicators of Children's Education}

Though shocks might affect time inputs into the education of children, we do not know if the effects are transitory or permanently affect the child's cognitive development. To investigate this, we estimate the effect of shocks on children's cognitive ability captured through vocabulary and mathematics tests conducted by the Young Lives survey. The receptive vocabulary skills of the children are captured through the PPVT Version III conducted in Telugu and English across Rounds 2-4. However, the raw scores of PPVT may not be appropriate for comparison across rounds since a subset of the test is same across rounds while the remaining items are different. Thus, we use standardized measures of PPVT by employing Item Response Theory (IRT). In IRT, scores are first estimated considering item's difficulty, discrimination, and pseudoguessing, they are then corrected for biases and then standardized across rounds. We present the effect of shocks for both raw scores and standardized scores. This is because PPVT scores could only be standardized for those who took the test in Telugu and those who took the test in English could not be included rendering a smaller sample. Also, such standardized scores could not be obtained for Mathematics for Rounds 2-4 since a different quantitative assessment was conducted in Round 2 and hence we do not have common items across rounds to employ IRT to standardize the scores. ${ }^{1}$

We find that livestock loss and paternal health shocks significantly affects the cognitive ability of children by lowering the math scores. This is because we found that these shocks reduce time spent in school by children. Increase in education expenditure might affect household financing of other goods, but it improves the cognitive ability of children through its positive effect on PPVT scores. We also find that drought improves both raw and standardized PPVT scores since it was found to have a positive effect on time spent in school and studying at home.

\footnotetext{
${ }^{1}$ Refer Young Lives (2017) for more information on IRT procedure followed in the study.
} 
Table 5: Effect of Shocks on Outcome Indicators of Children's Education

\begin{tabular}{|c|c|c|c|c|c|c|}
\hline \multirow[t]{3}{*}{ VARIABLES } & (1) & (2) & (3) & (4) & (5) & (6) \\
\hline & \multicolumn{2}{|c|}{ PPVT raw scores } & \multicolumn{2}{|c|}{ PPVT standardized scores } & \multicolumn{2}{|c|}{ Math raw scores } \\
\hline & coeff & se & coeff & se & coeff & se \\
\hline Lagged scores & 0.043 & 0.031 & $0.100 * * *$ & 0.034 & $0.199 * * *$ & 0.030 \\
\hline Crop shock & 0.020 & 0.053 & 0.055 & 0.039 & -0.040 & 0.045 \\
\hline Drought & $0.207 * *$ & 0.082 & $0.105^{*}$ & 0.061 & 0.113 & 0.070 \\
\hline Flood & 0.014 & 0.104 & 0.052 & 0.077 & 0.096 & 0.088 \\
\hline Livestock loss & -0.020 & 0.077 & 0.001 & 0.056 & $-0.175 * * *$ & 0.065 \\
\hline Father ill/died & -0.005 & 0.066 & -0.067 & 0.050 & $-0.123 * *$ & 0.055 \\
\hline Mother ill/dies & -0.062 & 0.071 & -0.057 & 0.054 & -0.075 & 0.059 \\
\hline Job loss & 0.045 & 0.142 & -0.049 & 0.122 & -0.017 & 0.116 \\
\hline Divorce & 0.017 & 0.284 & -0.263 & 0.204 & -0.150 & 0.232 \\
\hline Fertility shock & 0.148 & 0.135 & 0.087 & 0.105 & $-0.188^{*}$ & 0.109 \\
\hline Education expenditure & $0.168^{* *}$ & 0.086 & $0.114^{*}$ & 0.067 & -0.007 & 0.069 \\
\hline Housing damages & -0.114 & 0.233 & -0.131 & 0.165 & -0.098 & 0.185 \\
\hline Child's age & $0.020 * * *$ & 0.004 & $0.012 * * *$ & 0.003 & $0.021 * * *$ & 0.004 \\
\hline Female & $-0.115^{* * *}$ & 0.030 & $-0.072 * * *$ & 0.023 & 0.019 & 0.025 \\
\hline Eldest child & $0.114 * * *$ & 0.030 & $0.070 * * *$ & 0.023 & $0.094 * * *$ & 0.025 \\
\hline L. Head female & 0.107 & 0.089 & 0.026 & 0.067 & 0.117 & 0.075 \\
\hline L.head education & $0.015 * * *$ & 0.004 & $0.007 * *$ & 0.003 & $0.014 * * *$ & 0.004 \\
\hline Mother education & $0.036 * * *$ & 0.005 & $0.029 * * *$ & 0.004 & $0.049 * * *$ & 0.004 \\
\hline L.household size & -0.012 & 0.008 & 0.000 & 0.006 & $0.015^{* *}$ & 0.007 \\
\hline L.wealth index & $0.523 * * *$ & 0.131 & $0.505 * * *$ & 0.100 & $0.666 * * *$ & 0.109 \\
\hline OBC & $-0.117 * *$ & 0.055 & $-0.071^{*}$ & 0.043 & $-0.197 * * *$ & 0.046 \\
\hline SC & $-0.306 * * *$ & 0.060 & $-0.211 * * *$ & 0.047 & $-0.383 * * *$ & 0.051 \\
\hline ST & $-0.221 * * *$ & 0.046 & $-0.167 * * *$ & 0.037 & $-0.150 * * *$ & 0.039 \\
\hline Muslims & $-0.541 * * *$ & 0.077 & -0.104 & 0.076 & $-0.478 * * *$ & 0.064 \\
\hline L.Rural residence & 0.048 & 0.047 & -0.024 & 0.037 & $0.266 * * *$ & 0.039 \\
\hline Round 3 & $-2.172 * * *$ & 0.412 & -0.173 & 0.153 & $-2.659 * * *$ & 0.366 \\
\hline Round 4 & $-3.158 * * *$ & 0.606 & 0.000 & 0.000 & $-3.709 * * *$ & 0.539 \\
\hline Constant & 0.000 & 0.000 & $-1.497 * * *$ & 0.484 & 0.000 & 0.000 \\
\hline Observations & 3,280 & & 2,800 & & 3,329 & \\
\hline Number of children & 1,808 & & 1,540 & & 1,823 & \\
\hline
\end{tabular}

Note: L. stands for lagged values of the time-varying variables. $* * * p<0.01, * * p<0.05, * p<0.1$ Source: Author's own compilation based on Young Lives survey.

Male children and those of lower birth order have significantly higher achievement in both vocabulary and math skills. While children with educated and richer parents performed better, those from the disadvantaged backgrounds had poorer scores. This, in turn, implies that lower schooling inputs translate into lower cognitive achievement by children. 


\section{CONCLUSIONS}

In this study, we find that idiosyncratic shocks like paternal health shocks and livestock loss translate into lower inputs of children's education which in turn reduce their cognitive ability captured through vocabulary and mathematics tests. We also find that these shocks mainly affect children's development through decreased time spent in school. It is important to note that, a decrease in time spent in school might imply that children are taken out of school when households face negative income shocks. However, time spent at school does not capture a low percentage of attendance, if any, among the school-goers since the survey question only asks the number of hours a child typically spends on school-going day. If children maintain low attendance during seasons like floods and high attendance during other seasons, the data cannot capture the effect of shocks well since we do not know the average time spent in schools in the entire year. However, it might also be the case that children may be taken out of private school and enrolled in public schools in order to reduce the expenditure incurred by households on school fees etc. since in general, private schools are costlier than public schools. This, in turn, might lead to less time spent in schools since children enrolled in private schools spend more time studying (at school and at home) on an average than children enrolled in public schools. To verify the channels, we investigated the effect of shocks on enrolment in schools in general and enrolment in private schools. We find that paternal health shocks and livestock loss affect children's enrolment in general; however, we do not find evidence that shocks affect enrolment into private schools. Thus, we find that children are taken out of school and made to work in domestic or paid activities when households face idiosyncratic income shocks like health shocks and livestock loss and lack sufficient risk-coping mechanisms.

Children from poorer and more disadvantaged groups receive lesser investments in education which in turn translate into poorer cognitive achievements thus perpetuating inequality from one generation 
to next. This effect remains even after accounting for initial conditions like land and livestock possessed by the households in a different set of regressions. In another set of regressions, we consider wealth index, ownership of land, livestock and migration as endogenous variables, but the results obtained are similar. Effects of certain shocks might not be significant in the empirical analysis if the shocks are highly correlated with other shock variables, for instance, crop shock can be highly correlated with natural disasters like flood and drought. We also perform analysis by using only sub-sets of shocks and we find that the effects remain similar. Separate regressions for girls and boys are also conducted, but we do not find evidence that shocks have differential effects on boys and girls though we find that girls are in general disadvantaged compared to boys in terms of educational investments received which in turn affect their cognitive achievement. 


\section{REFERENCES}

Abiona, O. (2017). "Adverse Effects of Early Life Extreme Precipitation Shocks on Short term Health and Adulthood Welfare Outcomes". Review of Development Economics, 21(4), 12291254.

Arellano, M., S. Bond, 1991. "Some Tests of Specification for Panel Data: Monte Carlo Evidence and An Application to Employment Equations". Review of Economic Studies, 58, 277-297.

Arellano, M., and O. Bover, 1995. "Another Look at the Instrumental Variable Estimation of Error-components Models". Journal of Econometrics, 68, 29-51.

Beegle, K., R. Dehejia, and R. Gatti (2003). "Child Labor, Crop Shocks, and Credit Constraints (No. w10088)". National Bureau of Economic Research.

Cogneau, D., and R. Jedwab (2012). "Commodity Price Shocks and Child Outcomes: The 1990 Cocoa Crisis in Cote d'Ivoire". Economic Development and Cultural Change, 60(3), 507-534.

Crookston, B. T., R. Forste, C. McClellan, A. Georgiadis, and T. B. Heaton, (2014). "Factors Associated with Cognitive Achievement in Late Childhood and Adolescence: The Young Lives Cohort Study of Children in Ethiopia, India, Peru, and Vietnam". BMC pediatrics, 14(1), 253.

Dasgupta, B. and M. I. Ajwad (2011). "Income Shocks Reduce Human Capital Investments: Evidence from Five East European Countries". World Bank Policy Research Working Paper No. 5926.

De Janvry, A., F. Finan, E. Sadoulet, and R. Vakis, (2006). "Can Conditional Cash Transfer Programs Serve as Safety Nets in Keeping Children at School and from Working When Exposed to Shocks?" Journal of Development Economics, 79(2), 349-373.

Dinku, Y., D. Fielding, and M. Genç (2018). "Health Shocks and Child Time Allocation Decisions by Households: Evidence from Ethiopia". IZA Journal of Labor Economics, 71$), 4$. 
Duryea, S., D. Lam, and D. Levison (2007). "Effects of Economic Shocks on Children's Employment and Schooling in Brazil". Journal of Development Economics, 84(1), 188-214.

Evans, D. K., and E. Miguel, (2007). "Orphans and Schooling in Africa: A Longitudinal Analysis". Demography, 44(1), 35-57.

Ferreira, F. H., and Schady, N. (2009). "Aggregate Economic Shocks, Child Schooling, and Child Health". The World Bank Research Observer, 24(2), 147-181.

Fink, G., and P. C. Rockers (2014). "Childhood Growth, Schooling, and Cognitive Development: Further Evidence from the Young Lives Study". The American journal of clinical nutrition, 100(1), 182188.

Fitzsimons, E. (2007). "The Effects of Risk on Education in Indonesia". Economic Development and Cultural Change, 56(1), $1-25$.

Galab, S., S. V. Kumar, P. P. Reddy, R. Singh, and U. Vennam (2011). The Impact of Growth on Childhood Poverty in Andhra Pradesh: Initial Findings from India: Round 3 Survey Report. Young Lives, Department of International Development, University of Oxford.

Glick, P. J., D. E. Sahn, and T. F. Walker (2016). "Household Shocks and Education Investments in Madagascar". Oxford Bulletin of Economics and Statistics, 78(6), 792-813.

Guarcello, L., F. Mealli, and F. C. Rosati (2010). "Household Vulnerability and Child Labor: The Effect of Shocks, Credit Rationing, and Insurance". Journal of Population Economics, 23(1), 169-198.

Hansen, L. P. (1982). "Large Sample Properties of Generalized Method of Moments Estimators". Econometrica: Journal of the Econometric Society, 1029-1054.

Hou, X., S. Y. Hong, and K. Scott (2016). "The Heterogeneous Effects of a Food Price Crisis on Child School Enrolment and Labour: Evidence from Pakistan". The Journal of Development Studies, 52(5), 718-734. 
Jacoby, H. G., and E. Skoufias. (1997). "Risk, Financial Markets, and Human Capital in a Developing Country". The Review of Economic Studies, 64(3), 311-335.

Jensen, R. (2000). "Agricultural Volatility and Investments in Children". American Economic Review, 90(2), 399-404.

Koissy, K. S. A., M. Kuepie, and M. Tenikue. (2012). "Fertility Shock and Schooling (No. 2012-12)". The Luxembourg Institute of SocioEconomic Research.

Lundberg, M., and A. Wuermli (2012). Children and Youth in Crisis. Protecting and Promoting Human Development in Times of economic Shocks. Washington: World Bank.

Mileva, E. (2007). Using Arellano-Bond dynamic panel GMM estimators in Stata. Economics Department, Fordham University, 1-10.

Morduch, J. (1995). "Income Smoothing and Consumption Smoothing". Journal of Economic Perspectives, 9(3), 103-114.

Roodman, D. (2009). "How to Do Xtabond2: An Introduction to Difference and System GMM in Stata". Stata Journal, 9(1), 86136.

Shah, M., and B. M. Steinberg (2017). "Drought of Opportunities: Contemporaneous and Long-term Impacts of Rainfall Shocks on Human Capital". Journal of Political Economy, 125(2), 527-561.

Singh, K. (2011). "Impact of Adverse Economic Shocks on the Indian Child Labour Market and the Schooling of Children of Poor Households. (MPRA Paper, 30958)". University Library of Munich, Germany.

Singh, R., and S. Sarkar (2015). "Does Teaching Quality Matter? Students Learning Outcome Related to Teaching Quality in Public and Private Primary Schools in India". International Journal of Educational Development, 41, 153-163.

Sun, A., and Y. Yao (2010). "Health Shocks and Children's School Attainments in Rural China". Economics of Education Review, 29(3), 375-382. 
Thai, T. Q., and E. M. Falaris (2014). "Child Schooling, Child Health, and Rainfall Shocks: Evidence from Rural Vietnam". Journal of Development Studies, 50(7), 1025-1037.

Thomas, D., K. Beegle, E. Frankenberg, B. Sikoki, J. Strauss, and G. Teruel (2004). "Education in a Crisis". Journal of Development economics, 74(1), 53-85.

Woode, M. E. (2017). "Parental Health Shocks and Schooling: The Impact of Mutual Health Insurance in Rwanda". Social Science and Medicine, 173, 35-47.

Zamand, M., and A. Hyder (2016). "Impact of Climatic Shocks on Child Human Capital: Evidence from Young Lives Data". Environmental hazards, 15(3), 246-268. 


\section{APPENDIX A}

Table A1: Summary Statistics of Household Characteristics

Across Rounds

\begin{tabular}{|c|c|c|c|c|}
\hline \multirow[t]{2}{*}{ Variable } & \multicolumn{4}{|c|}{ Younger Cohort } \\
\hline & R1 & $\mathbf{R 2}$ & R3 & R4 \\
\hline $\begin{array}{l}\text { Age of the child in } \\
\text { months }\end{array}$ & 40.36 & 92.99 & 124.05 & 171.62 \\
\hline Female child & $\begin{array}{r}47.93 \\
\text { percent }\end{array}$ & $\begin{array}{r}48.00 \\
\text { percent }\end{array}$ & $\begin{array}{r}47.99 \\
\text { percent }\end{array}$ & $\begin{array}{r}47.76 \\
\text { percent }\end{array}$ \\
\hline Eldest child & 55.20 & 55.44 & 55.15 & 55.09 \\
\hline $\begin{array}{l}\text { Age of the household } \\
\text { head }\end{array}$ & 40.0 & 38.5 & 38.6 & 41.2 \\
\hline Male household heads & .6 percent & 94.8 percent & 94.6 percent & 89.5 percent \\
\hline $\begin{array}{l}\text { No. of years of } \\
\text { education of the } \\
\text { household head }\end{array}$ & 3.4 & 4.7 & 5.4 & 6.5 \\
\hline $\begin{array}{l}\text { No. of years of } \\
\text { education of mother }\end{array}$ & 2.4 & 2.9 & 3.3 & 3.6 \\
\hline Household size & 5.4 & 5.5 & 5.4 & 4.9 \\
\hline Dependency ratio & 0.3 & 0.2 & 0.2 & 0.2 \\
\hline Wealth Index & 0.4 & 0.5 & 0.5 & 0.6 \\
\hline $\begin{array}{l}\text { Land owned (in } \\
\text { hectares) }\end{array}$ & 0.8 & 0.7 & 0.7 & 0.7 \\
\hline Ownership of livestock & 44 percent & 39 percent & 41 percent & 43 percent \\
\hline Ethnicit SC & 21.0 percent & 21.1 percent & 21.0 percent & 21.2 percent \\
\hline y ST & 10.8 percent & 10.8 percent & 10.9 percent & 11.2 percent \\
\hline $\mathrm{BC}$ & 46.4 percent & 46.5 percent & 46.6 percent & 46.3 percent \\
\hline \begin{tabular}{|l} 
Others, \\
Muslim
\end{tabular} & 6.2 percent & 6.1 percent & 6.1 percent & 6.0 percent \\
\hline \begin{tabular}{|l|} 
Others, \\
Hindu, \\
Christian, \\
Buddhist \\
\end{tabular} & 15.6 percent & 15.5 percent & 15.5 percent & 15.3 percent \\
\hline Rural residence & 75.1 percent & 75.5 percent & 75.1 percent & \begin{tabular}{|l}
69.8 percent \\
\end{tabular} \\
\hline Migration & 0.0 percent & 4.5 percent & 7.1 percent & 21.6 percent \\
\hline
\end{tabular}

Source: Authors' own compilation based on Young Lives survey data. 


\section{APPENDIX B}

Table B1: Differences in Questionnaires Across Rounds

\begin{tabular}{|c|c|c|c|c|}
\hline Shocks & Round 1 & Round 2 & Round 3 & Round 4 \\
\hline Questions & $\begin{array}{l}\text { Since you } \\
\text { found you/ } \\
\text { 'NAME's' } \\
\text { mother was } \\
\text { pregnant with } \\
\text { 'NAME' have } \\
\text { there been } \\
\text { any big } \\
\text { changes or } \\
\text { events that } \\
\text { decreased the } \\
\text { economic } \\
\text { welfare of } \\
\text { your } \\
\text { household? }\end{array}$ & $\begin{array}{l}\text { Now I am going to } \\
\text { ask you about the } \\
\text { most important } \\
\text { events and changes } \\
\text { that have happened } \\
\text { since the last time } \\
\text { we came to see } \\
\text { you. }\end{array}$ & $\begin{array}{l}\text { Now I am going } \\
\text { to ask you about } \\
\text { the most } \\
\text { important events } \\
\text { and changes that } \\
\text { have happened } \\
\text { (that affected the } \\
\text { household } \\
\text { economy } \\
\text { negatively) since } \\
\text { the last time we } \\
\text { came to see you. }\end{array}$ & $\begin{array}{l}\text { Now I am going } \\
\text { to ask you about } \\
\text { the most } \\
\text { important events } \\
\text { and changes that } \\
\text { have happened } \\
\text { (that negatively } \\
\text { affected the } \\
\text { household } \\
\text { economy) since } \\
2010 .\end{array}$ \\
\hline Crop loss / & Crops failed & Crops failed & Crop failed & Crops failed \\
\hline Damage & & $\begin{array}{l}\text { Pests or diseases } \\
\text { that affected crops } \\
\text { before they were } \\
\text { harvested }\end{array}$ & $\begin{array}{l}\text { Pests or diseases } \\
\text { that affected } \\
\text { crops before they } \\
\text { were harvested }\end{array}$ & $\begin{array}{l}\text { Pests or diseases } \\
\text { that affected } \\
\text { crops before they } \\
\text { were harvested }\end{array}$ \\
\hline & & $\begin{array}{l}\text { Pests or diseases } \\
\text { that led to storage } \\
\text { losses }\end{array}$ & $\begin{array}{l}\text { Pests or diseases } \\
\text { that led to } \\
\text { storage losses } \\
\end{array}$ & $\begin{array}{l}\text { Pests or diseases } \\
\text { that led to } \\
\text { storage losses }\end{array}$ \\
\hline \multirow{2}{*}{$\begin{array}{l}\text { Livestock } \\
\text { loss/ } \\
\text { disease }\end{array}$} & Livestock died & Livestock died & Livestock died & Livestock died \\
\hline & & $\begin{array}{l}\text { Pests or diseases } \\
\text { that affected } \\
\text { livestock }\end{array}$ & $\begin{array}{l}\text { Pests or } \\
\text { Diseases that } \\
\text { affected livestock }\end{array}$ & $\begin{array}{l}\text { Pests or diseases } \\
\text { that affected } \\
\text { livestock }\end{array}$ \\
\hline \multirow[t]{5}{*}{$\begin{array}{l}\text { Health } \\
\text { shock }\end{array}$} & $\begin{array}{l}\text { Death/ } \\
\text { reduction in } \\
\text { household } \\
\text { members } \\
\end{array}$ & & & \\
\hline & \begin{tabular}{|l|} 
Severe Illness \\
or injury \\
\end{tabular} & & & \\
\hline & & $\begin{array}{l}\text { Death of child's } \\
\text { father }\end{array}$ & $\begin{array}{l}\text { Death of NAME'S } \\
\text { Father }\end{array}$ & $\begin{array}{l}\text { Death of [YL } \\
\text { Child]'s father }\end{array}$ \\
\hline & & $\begin{array}{l}\text { Death of child's } \\
\text { Mother }\end{array}$ & $\begin{array}{l}\text { Death of NAME'S } \\
\text { Mother }\end{array}$ & $\begin{array}{l}\text { Death of [YL } \\
\text { Child]'s mother }\end{array}$ \\
\hline & & $\begin{array}{l}\text { Death of another } \\
\text { person from the } \\
\text { household }\end{array}$ & $\begin{array}{l}\text { Death of another } \\
\text { person in the } \\
\text { household }\end{array}$ & $\begin{array}{l}\text { Death of another } \\
\text { person in the } \\
\text { household }\end{array}$ \\
\hline
\end{tabular}




\begin{tabular}{|c|c|c|c|c|}
\hline \multirow[t]{5}{*}{ Shocks } & Round 1 & Round 2 & Round 3 & Round 4 \\
\hline & & $\begin{array}{l}\text { Illness of child's } \\
\text { father }\end{array}$ & $\begin{array}{l}\text { Illness of NAME'S } \\
\text { Father }\end{array}$ & $\begin{array}{l}\text { Illness of [YL } \\
\text { Child]'s father }\end{array}$ \\
\hline & & $\begin{array}{l}\text { Illness of child's } \\
\text { mother }\end{array}$ & $\begin{array}{l}\text { Illness of } \\
\text { NAME'S Mother }\end{array}$ & $\begin{array}{l}\text { Illness of [YL } \\
\text { Child]'s mother }\end{array}$ \\
\hline & & $\begin{array}{l}\text { Illness of another } \\
\text { household member }\end{array}$ & & $\begin{array}{l}\text { Illness of another } \\
\text { household } \\
\text { member }\end{array}$ \\
\hline & & & & $\begin{array}{l}\text { Illness of non- } \\
\text { household } \\
\text { member }\end{array}$ \\
\hline \multirow[t]{5}{*}{$\begin{array}{l}\text { Natural } \\
\text { Disaster }\end{array}$} & $\begin{array}{l}\text { Natural } \\
\text { Disaster }\end{array}$ & & & \\
\hline & & Drought & Drought & Drought \\
\hline & & $\begin{array}{l}\text { Too much rain or } \\
\text { flood }\end{array}$ & $\begin{array}{l}\text { Too much rain or } \\
\text { flood }\end{array}$ & $\begin{array}{l}\text { Too much rain or } \\
\text { flood }\end{array}$ \\
\hline & & Erosion & \begin{tabular}{|l|} 
Erosion, Cracks \\
or landslide
\end{tabular} & $\begin{array}{l}\text { Erosion, Cracks or } \\
\text { landslide }\end{array}$ \\
\hline & & Frosts or hailstorm & $\begin{array}{l}\text { Frosts or } \\
\text { hailstorm }\end{array}$ & $\begin{array}{l}\text { Frosts or } \\
\text { hailstorm }\end{array}$ \\
\hline $\begin{array}{l}\text { Fertility } \\
\text { Shock }\end{array}$ & $\begin{array}{l}\text { Birth/new } \\
\text { household } \\
\text { member }\end{array}$ & $\begin{array}{l}\text { Birth/new } \\
\text { household member }\end{array}$ & $\begin{array}{l}\text { Birth new } \\
\text { household } \\
\text { member }\end{array}$ & $\begin{array}{l}\text { Birth/new } \\
\text { household } \\
\text { member }\end{array}$ \\
\hline $\begin{array}{l}\text { Divorce/ } \\
\text { Separation }\end{array}$ & $\begin{array}{l}\text { Divorced or } \\
\text { separated }\end{array}$ & $\begin{array}{l}\text { Divorce, separation } \\
\text { or abandonment }\end{array}$ & $\begin{array}{l}\text { Divorce, } \\
\text { Separation or } \\
\text { abandonment }\end{array}$ & $\begin{array}{l}\text { Divorce, } \\
\text { separation or } \\
\text { abandonment }\end{array}$ \\
\hline $\begin{array}{l}\text { Education } \\
\text { expenditure }\end{array}$ & $\begin{array}{l}\text { Paying for } \\
\text { child's } \\
\text { education }\end{array}$ & $\begin{array}{l}\text { Child's school } \\
\text { enrolment - having } \\
\text { to pay school fees }\end{array}$ & $\begin{array}{l}\text { Child's school } \\
\text { enrolment-having } \\
\text { to pay school } \\
\text { fees }\end{array}$ & $\begin{array}{l}\text { Child's school } \\
\text { enrolment - } \\
\text { having to pay } \\
\text { school fees } \\
\end{array}$ \\
\hline \multirow[t]{6}{*}{ Crime } & $\begin{array}{l}\text { Victim of } \\
\text { Crime }\end{array}$ & & & \\
\hline & Crops stolen & Theft of crops & & \\
\hline & $\begin{array}{l}\text { Livestock } \\
\text { stolen }\end{array}$ & Theft of livestock & & \\
\hline & & $\begin{array}{l}\text { Destruction or } \\
\text { theft of tools or } \\
\text { inputs for } \\
\text { production }\end{array}$ & & \\
\hline & & Theft of cash & & \\
\hline & & $\begin{array}{l}\text { Theft/destruction of } \\
\text { housing/consumer } \\
\text { goods }\end{array}$ & & \\
\hline
\end{tabular}




\begin{tabular}{|c|c|c|c|c|}
\hline \multirow[t]{4}{*}{ Shocks } & Round 1 & Round 2 & Round 3 & Round 4 \\
\hline & & $\begin{array}{l}\text { Crime resulting in } \\
\text { death or } \\
\text { disablement of } \\
\text { working adult } \\
\text { household member }\end{array}$ & & \\
\hline & & Imprisonment & & \\
\hline & & & $\begin{array}{l}\text { Theft or } \\
\text { destruction }\end{array}$ & $\begin{array}{l}\text { Theft or } \\
\text { destruction (e.g. } \\
\text { cash, crops, } \\
\text { livestock, } \\
\text { destruction of } \\
\text { housing) }\end{array}$ \\
\hline \multirow[t]{3}{*}{$\begin{array}{l}\text { Price } \\
\text { fluctuations }\end{array}$} & & $\begin{array}{l}\text { Large increase in } \\
\text { input prices }\end{array}$ & $\begin{array}{l}\text { Large Increase in } \\
\text { input price }\end{array}$ & $\begin{array}{l}\text { Large increase in } \\
\text { input prices }\end{array}$ \\
\hline & & $\begin{array}{l}\text { Large decrease in } \\
\text { output prices }\end{array}$ & $\begin{array}{l}\text { Large decrease } \\
\text { in output prices }\end{array}$ & $\begin{array}{l}\text { Large decrease in } \\
\text { output prices }\end{array}$ \\
\hline & & & $\begin{array}{l}\text { Increase in the } \\
\text { price of food that } \\
\text { I buy }\end{array}$ & $\begin{array}{l}\text { Increase in the } \\
\text { price of food that } \\
\text { I buy }\end{array}$ \\
\hline \multirow[t]{2}{*}{ Job loss } & $\begin{array}{l}\text { Job loss/ } \\
\text { source of } \\
\text { income/ family } \\
\text { enterprises }\end{array}$ & $\begin{array}{l}\text { Job loss/source of } \\
\text { income/ family } \\
\text { enterprise }\end{array}$ & $\begin{array}{l}\text { Job loss/ source } \\
\text { of income/ family } \\
\text { enterprise }\end{array}$ & \begin{tabular}{|l|} 
Job loss/ source \\
of income/ family \\
enterprise
\end{tabular} \\
\hline & & $\begin{array}{l}\text { Place of } \\
\text { employment } \\
\text { shutdown/ } \\
\text { destroyed }\end{array}$ & & \\
\hline \multirow{3}{*}{\begin{tabular}{|l|} 
Housing \\
Damages
\end{tabular}} & & Fire & & \\
\hline & & Building collapsed & & \\
\hline & & & $\begin{array}{l}\text { Fire or collapse of } \\
\text { building }\end{array}$ & $\begin{array}{l}\text { Fire or collapse } \\
\text { of building }\end{array}$ \\
\hline \multirow{6}{*}{$\begin{array}{l}\text { Regulatory } \\
\text { and } \\
\text { economic } \\
\text { shocks }\end{array}$} & & $\begin{array}{l}\text { Conscription, } \\
\text { abduction or draft }\end{array}$ & & \\
\hline & & $\begin{array}{l}\text { Land redistribution } \\
\text { in the PA }\end{array}$ & & \\
\hline & & $\begin{array}{l}\text { Resettlement, } \\
\text { forced migration }\end{array}$ & & \\
\hline & & $\begin{array}{l}\text { Ban or restrictions } \\
\text { on migration }\end{array}$ & & \\
\hline & & Eviction & & \\
\hline & & Industrial action & & \\
\hline
\end{tabular}




\begin{tabular}{|c|c|c|c|c|}
\hline Shocks & Round 1 & Round 2 & Round 3 & Round 4 \\
\hline & & $\begin{array}{l}\text { Contract disputes } \\
\text { regarding } \\
\text { purchased inputs }\end{array}$ & & \\
\hline & & $\begin{array}{l}\text { Contract disputes } \\
\text { regarding sale of } \\
\text { output }\end{array}$ & & \\
\hline & & $\begin{array}{l}\text { Credit source } \\
\text { disbanded }\end{array}$ & & \\
\hline & & $\begin{array}{l}\text { Confiscation of } \\
\text { assets }\end{array}$ & & \\
\hline & & $\begin{array}{l}\text { Disputes with } \\
\text { extended family } \\
\text { members regarding } \\
\text { land or assets }\end{array}$ & & \\
\hline & & $\begin{array}{l}\text { Forced } \\
\text { contributions or } \\
\text { arbitrary taxation or } \\
\text { protection money }\end{array}$ & $\begin{array}{l}\text { Forced } \\
\text { contributions or } \\
\text { arbitrary taxation } \\
\text { or protection } \\
\text { money }\end{array}$ & $\begin{array}{l}\text { Forced } \\
\text { contributions or } \\
\text { arbitrary taxation } \\
\text { or protection } \\
\text { money }\end{array}$ \\
\hline & & $\begin{array}{l}\text { Disputes with } \\
\text { neighbours/ PA } \\
\text { members regarding } \\
\text { land or assets }\end{array}$ & $\begin{array}{l}\text { Disputes with } \\
\text { neighbours/PA } \\
\text { members } \\
\text { regarding land } \\
\text { and assets } \\
\end{array}$ & $\begin{array}{l}\text { Disputes with } \\
\text { neighbours/ } \\
\text { village members } \\
\text { regarding land or } \\
\text { assets }\end{array}$ \\
\hline & \begin{tabular}{|l} 
Decrease, \\
change in food \\
availability \\
\end{tabular} & & & \\
\hline & $\begin{array}{l}\text { Moved/ } \\
\text { migrated/ fled }\end{array}$ & & & \\
\hline \begin{tabular}{|l|} 
Other \\
Shocks
\end{tabular} & Other & Others & Others & Other, specify \\
\hline
\end{tabular}

Source: Authors' own compilation based on Young Lives questionnaires. 
Table B2: Shocks Faced By Households Across Rounds

\begin{tabular}{|c|c|c|c|c|c|}
\hline \multirow[t]{2}{*}{ Shocks } & \multirow{2}{*}{ Variable names } & \multicolumn{4}{|c|}{ Younger Cohort } \\
\hline & & R1 & R2 & R3 & R4 \\
\hline \multirow{3}{*}{$\begin{array}{c}\text { Crop loss / } \\
\text { damage }\end{array}$} & Crop failure & 28.2 & 13.4 & 18.6 & 21.6 \\
\hline & Pests on crops & - & 7.2 & 8.1 & 3.9 \\
\hline & $\begin{array}{l}\text { Pests or diseases } \\
\text { that led to storage } \\
\text { losses }\end{array}$ & - & 0.4 & 0.8 & 0.5 \\
\hline \multirow{2}{*}{$\begin{array}{l}\text { Livestock loss/ } \\
\text { disease }\end{array}$} & Death of livestock & 5.8 & 5.7 & 6.7 & 7.4 \\
\hline & Pests on livestock & - & 1.0 & 2.3 & 0.8 \\
\hline \multirow[t]{9}{*}{ Health shock } & $\begin{array}{l}\text { Death/ reduction } \\
\text { household members }\end{array}$ & 2.9 & - & - & - \\
\hline & $\begin{array}{l}\text { Severe illness or } \\
\text { injury }\end{array}$ & 16.6 & - & - & - \\
\hline & Death of father & - & 1.3 & 1.8 & 2.0 \\
\hline & Death of mother & - & 0.5 & 0.8 & 0.8 \\
\hline & $\begin{array}{l}\text { Death of another } \\
\text { household member }\end{array}$ & - & 6.8 & 5.0 & 6.0 \\
\hline & Illness of father & - & 8.1 & 7.1 & 8.7 \\
\hline & Illness of mother & - & 8.0 & 7.2 & 9.7 \\
\hline & $\begin{array}{l}\text { Illness of another } \\
\text { household member }\end{array}$ & - & 10.0 & - & 10.3 \\
\hline & $\begin{array}{l}\text { Illness of non- } \\
\text { household member }\end{array}$ & - & - & - & 0.6 \\
\hline \multirow[t]{5}{*}{ Natural Disaster } & Natural disaster & 22.3 & - & - & - \\
\hline & Drought & - & 27.8 & 7.0 & 10.2 \\
\hline & Flooding & - & 5.9 & 2.6 & 5.4 \\
\hline & Erosion & - & - & 0.6 & - \\
\hline & Frost & - & 0.3 & 0.4 & 0.3 \\
\hline Fertility Shock & $\begin{array}{l}\text { Birth of new } \\
\text { household member }\end{array}$ & 7.4 & 18.4 & 4.5 & 1.1 \\
\hline Divorce/Separation & Divorce or separation & 1.4 & 3.5 & 1.2 & 0.7 \\
\hline $\begin{array}{l}\text { Education } \\
\text { expenditure }\end{array}$ & $\begin{array}{l}\text { Enrolment of child in } \\
\text { school }\end{array}$ & 3.2 & 4.1 & 7.5 & 3.5 \\
\hline \multirow{4}{*}{ Crime } & Victim of crime & 3.0 & - & - & - \\
\hline & Theft of crops & 2.8 & 0.6 & - & - \\
\hline & Theft of livestock & 1.0 & 1.0 & - & - \\
\hline & $\begin{array}{l}\text { Destruction/theft of } \\
\text { tools of production }\end{array}$ & - & 0.9 & - & - \\
\hline
\end{tabular}




\begin{tabular}{|c|c|c|c|c|c|}
\hline \multirow[t]{7}{*}{ Shocks } & \multirow[t]{2}{*}{ Variable names } & \multicolumn{4}{|c|}{ Younger Cohort } \\
\hline & & R1 & $\mathbf{R 2}$ & R3 & R4 \\
\hline & Theft of cash & - & 1.7 & - & - \\
\hline & $\begin{array}{l}\text { Theft/destruction of } \\
\text { housing/consumer } \\
\text { goods }\end{array}$ & - & 1.7 & - & - \\
\hline & $\begin{array}{l}\text { Crime that resulted in } \\
\text { death/disablement }\end{array}$ & - & 0.1 & - & - \\
\hline & Imprisonment & - & 0.4 & - & - \\
\hline & $\begin{array}{l}\text { Theft/destruction of } \\
\text { cash, crops, livestock }\end{array}$ & - & 5.4 & 4.2 & 1.9 \\
\hline \multirow[t]{3}{*}{ Price fluctuations } & Increase input prices & - & 9.7 & 9.8 & 3.5 \\
\hline & $\begin{array}{l}\text { Decrease output } \\
\text { prices }\end{array}$ & - & 3.9 & 8.4 & 4.9 \\
\hline & $\begin{array}{l}\text { Increase in food } \\
\text { prices }\end{array}$ & - & - & 78.6 & 49.6 \\
\hline \multirow[t]{2}{*}{ Job loss } & Job loss & 5.1 & 1.2 & 1.4 & 1.8 \\
\hline & $\begin{array}{l}\text { Closure place of } \\
\text { employment }\end{array}$ & - & 0.4 & - & - \\
\hline \multirow[t]{3}{*}{ Housing Damages } & Fire affecting house & - & 0.6 & - & - \\
\hline & House collapse & - & 1.1 & - & - \\
\hline & $\begin{array}{l}\text { Fire or collapse of } \\
\text { building }\end{array}$ & - & 1.6 & 1.2 & 0.2 \\
\hline \multirow[t]{10}{*}{$\begin{array}{l}\text { Regulatory and } \\
\text { economic shocks }\end{array}$} & $\begin{array}{l}\text { Conscription, } \\
\text { abduction or draft }\end{array}$ & - & 0.1 & - & - \\
\hline & Land redistribution & - & 0.2 & - & - \\
\hline & $\begin{array}{l}\text { Resettlement or } \\
\text { forced migration }\end{array}$ & - & 2.2 & - & - \\
\hline & $\begin{array}{l}\text { Restrictions on } \\
\text { migration }\end{array}$ & - & 0.1 & - & - \\
\hline & Eviction & - & 0.1 & - & - \\
\hline & Industrial action & - & - & - & - \\
\hline & $\begin{array}{l}\text { Contract disputes } \\
\text { (purchase of inputs) }\end{array}$ & - & 0.1 & - & - \\
\hline & $\begin{array}{l}\text { Contract disputes } \\
\text { (sale of output) }\end{array}$ & - & 0.1 & - & - \\
\hline & Disbanding credit & - & 1.9 & - & - \\
\hline & Confiscation of assets & - & 0.4 & - & - \\
\hline
\end{tabular}




\begin{tabular}{|c|l|c|c|c|c|}
\hline \multirow{3}{*}{ Shocks } & Variable names & \multicolumn{4}{|l|}{ Younger Cohort } \\
\cline { 2 - 6 } & & R1 & R2 & R3 & R4 \\
\cline { 2 - 6 } & $\begin{array}{l}\text { Disputes with family } \\
\text { about assets }\end{array}$ & - & 1.1 & - & - \\
\cline { 2 - 6 } & Forced contributions & - & 0.1 & 0.8 & 0.4 \\
\cline { 2 - 6 } & $\begin{array}{l}\text { Disputes with } \\
\text { neighbours about } \\
\text { assets }\end{array}$ & - & 0.6 & 2.3 & 0.9 \\
\hline Other shocks & $\begin{array}{l}\text { Decrease in food } \\
\text { availability }\end{array}$ & 5.3 & - & - & - \\
\cline { 2 - 6 } & Move/ migration & 3.4 & - & - & - \\
\cline { 2 - 7 } & Other shocks & 2.9 & 2.6 & 8.9 & 3.5 \\
\hline
\end{tabular}

Source: Authors' own compilation based on Young Lives survey data. 


\section{MSE Monographs}

* $\quad$ Monograph 30/2014

Counting The Poor: Measurement And Other Issues

C. Rangarajan and S. Mahendra Dev

* $\quad$ Monograph 31/2015

Technology and Economy for National Development: Technology Leads to Nonlinear Growth

Dr. A. P. J. Abdul Kalam, Former President of India

* $\quad$ Monograph 32/2015

India and the International Financial System

Raghuram Rajan

* Monograph 33/2015

Fourteenth Finance Commission: Continuity, Change and Way Forward

Y.V. Reddy

* $\quad$ Monograph 34/2015

Farm Production Diversity, Household Dietary Diversity and Women's BMI: A Study of Rural Indian Farm Households

Brinda Viswanathan

* Monograph 35/2016

Valuation of Coastal and Marine Ecosystem Services in India: Macro Assessment K. S. Kavi Kumar, Lavanya Ravikanth Anneboina, Ramachandra Bhatta, P. Naren, Megha Nath, Abhijit Sharan, Pranab Mukhopadhyay, Santadas Ghosh,

Vanessa da Costa and Sulochana Pednekar

* Monograph 36/2017

Underlying Drivers of India's Potential Growth

C.Rangarajan and D.K. Srivastava

* Monograph 37/2018

India: The Need for Good Macro Policies ( $4^{\text {th }}$ Dr. Raja J. Chelliah Memorial Lecture) Ashok K. Lahiri

* $\quad$ Monograph 38/2018

Finances of Tamil Nadu Government

KR Shanmugam

* $\quad$ Monograph 39/2018

Growth Dynamics of Tamil Nadu Economy

$K R$ Shanmugam 


\section{MSE Working Papers \\ Recent Issues}

* Working Paper 168/2017

Calendar Anomaly and the Degree of Market Inefficiency of Bitcoin

S. Raja Sethu Durai, Sunil Paul

* Working Paper 169/2018

Modelling the Characteristics of Residential Energy Consumption: Empirical

Evidence of Indian Scenario

Zareena Begum Irfan, Divya Jain, Satarupa Rakshit, Ashwin Ram

* Working Paper 170/2018

Catalyst Role of Indian Railways in Empowering Economy: Freight or Passenger

Segment is on the Fast Track of Expansion or Exploitation?

Zareena Begum Irfan, Shivani Gupta, Ashwin Ram, Satarupa Rakshit

* Working Paper 171/2018

Sustainable Debt Policies of Indian State Governments

P.S. Renjith, K. R. Shanmugam

* Working Paper 172/2018

Sustainability and Efficiency of Microfinance Institutions in South Asia

Brijesh C. Purohit, S. Saravanan

* Working Paper 173/2018

Corporate Governance Practices in India

Ekta Selarka

* Working Paper 174/2018

Current Status of Mangroves in India: Benefits, Rising Threats Policy and

Suggestions for the Way Forward

Samyuktha Ashokkumar, Zareena Begum Irfan

* Working Paper 175/2018

Current Status of Coral Reefs in India: Importance, Rising Threats and Policies for its Conservation and Management

Srihitha Baswapoor, Zareena Begum Irfan

* Working Paper 176/2018

Family Structure, Education and Women's Employment in Rural India Sowmya Dhanaraj, Vidya Mahambare

* Working papers are downloadable from MSE website http://www.mse.ac.in \$ Restricted circulation 